\title{
Suitability of thermal plasma for solid waste treatment and non-thermal plasma for nano-scale high-tech plasmonic materials: a concise review
}

\author{
Shahab Ud-Din Khan ${ }^{1} \cdot$ Riaz Khan $^{1} \cdot$ Shahid Hussain $^{1}$ \\ Received: 17 November 2021 / Accepted: 1 January 2022 / Published online: 7 February 2022 \\ (c) King Abdulaziz City for Science and Technology 2022
}

\begin{abstract}
In the recent past, plasma waste technology has emerged to be an environmental friendly and beneficial technology. In this review, current status of thermal plasma, non-thermal plasma and its application for nano-scale high-tech plasmonic materials based on the scientific and technical comprehensive observation are included. Generally, thermal plasma is used for solid waste treatment but non-thermal plasma is being utilized for plasmonic materials. The current research incorporated in two phases: thermal plasma and non-thermal plasma. In the first phase, understanding and detailed information about plasma torches have been included such as DC transfer and non-transfer arc plasma torches. In addition, solid waste treatment, municipal waste, healthcare issue, steel making and treatment through plasma jet injection have been reviewed extensively. In the second phase, state-of-the-art review has been addressed for dielectric barrier discharge (DBD) and its utility for plasmonic materials. The analysis concluded that the thermal plasma is the optimal choice for treating solid waste issues and the application of non-thermal plasma such as DBD is the most useful and latest approach for plasmonic material. The prime objective of this review is not only to provide the comparison between thermal or non-thermal plasma but to recommend the ideal and most optimized suitable technique for solid waste treatment and bio-medical applications.
\end{abstract}

Keywords Thermal plasma $\cdot$ Non-thermal plasma $\cdot$ Solid waste $\cdot$ Health care $\cdot$ Plasmonic materials

\section{Introduction}

The state of matter having identical temperature value for both heavy particles and electrons characterized by high energy density is termed as 'thermal plasma' while a nonthermal plasma is obtained using less power which is characterized by an energetic electron temperature (Jiang et al. 2014). It is important to use the thermal plasma technologies for waste treatment and non-thermal for bio-medical issues. For this purpose, a comprehensive and detailed scientific literatures are presented in this review report supported by Table 1 . There are certain ways from which it is possible to extract liquid wastes for example, drained oil from chemical and automobile industries; chemical solutions/solvents from industries; highly toxic waste fluids

Shahab Ud-Din Khan

Shahab.furqan@gmail.com

1 Pakistan Tokamak Plasma Research Institute, PO Box 3329, Islamabad, Pakistan
(PCBs) from mechanical/electronic factories; and depleted fluid such as halon and chlorofluorocarbons. While, solid waste has its origin from industrial wastes including toxic graded plastic, tires, petroleum by products; medical wastes derived from pharmaceutical industry and hospitals; waste from municipality; and conducting material wastes from electronic industries.

This review comprised of two sections, providing the thermal plasma treatment for solid waste and demonstrates the latest application of non-thermal plasmas. In the first section, plasma torches such as DC transfer arc plasma torches and DC non-transfer arc plasma torches are presented. In addition, plasma treatments for the processing of solid waste is discussed. In the second section, a newly developed method are discussed for plasmonic nano-material, which is an interesting material for diverse applications such as energy utilities, solar/fuel cells and sensor, solid, medical issues and laboratory equipment. Presently, number of novel methods are available for the treatment of plasma waste. In this review, we emphasize on the approaches which are practicing or under developing phase for solid waste and 


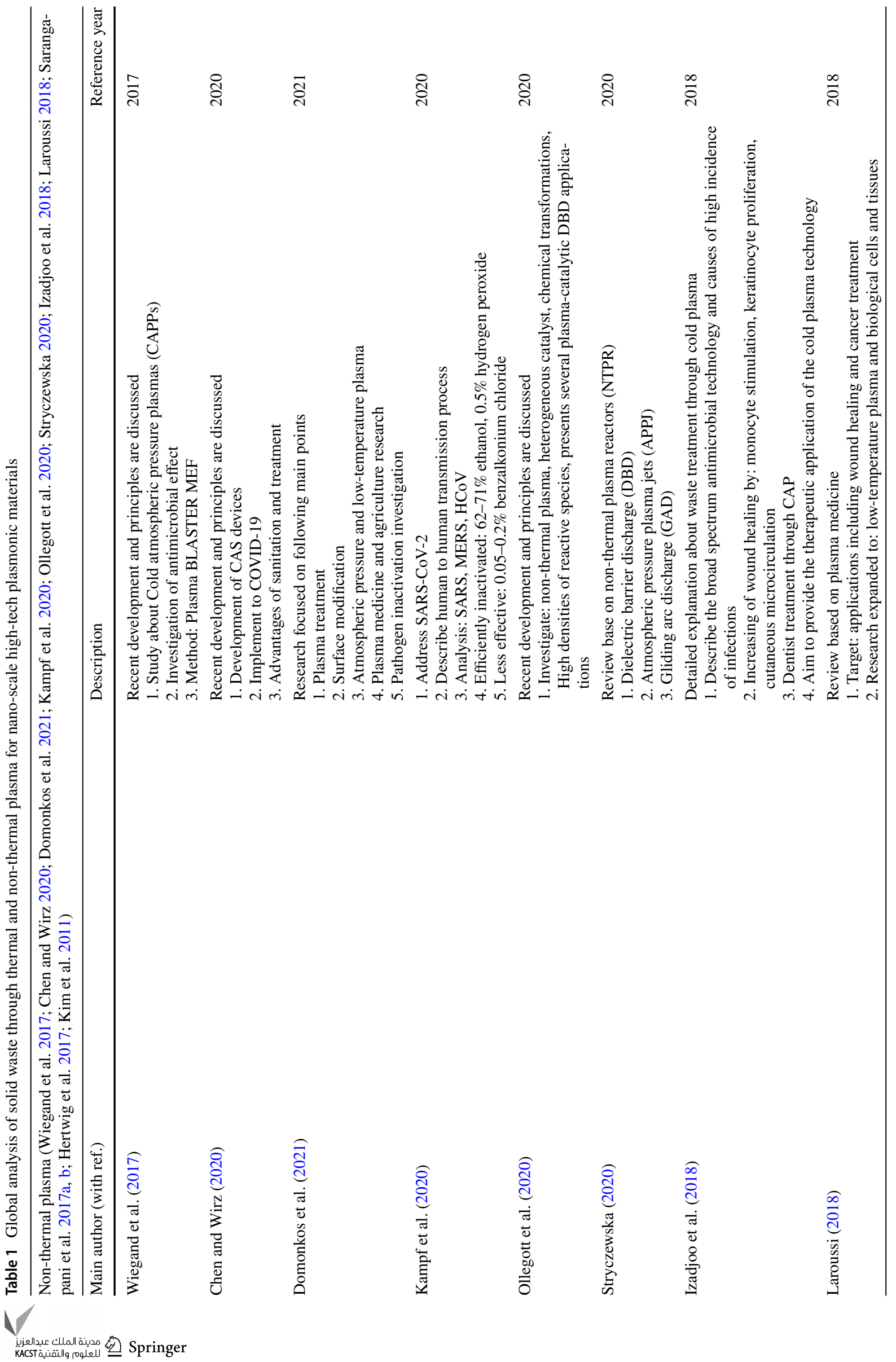




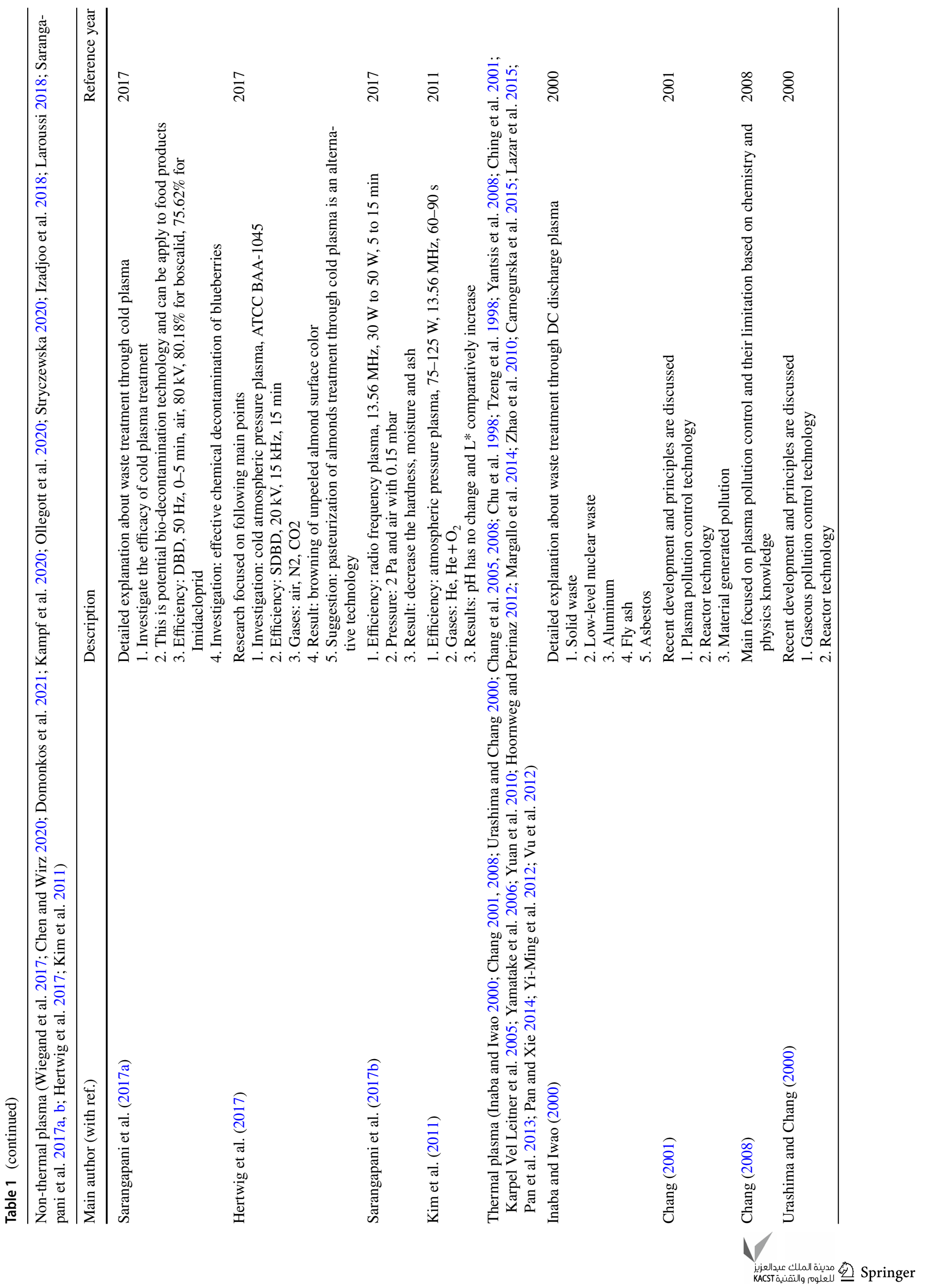




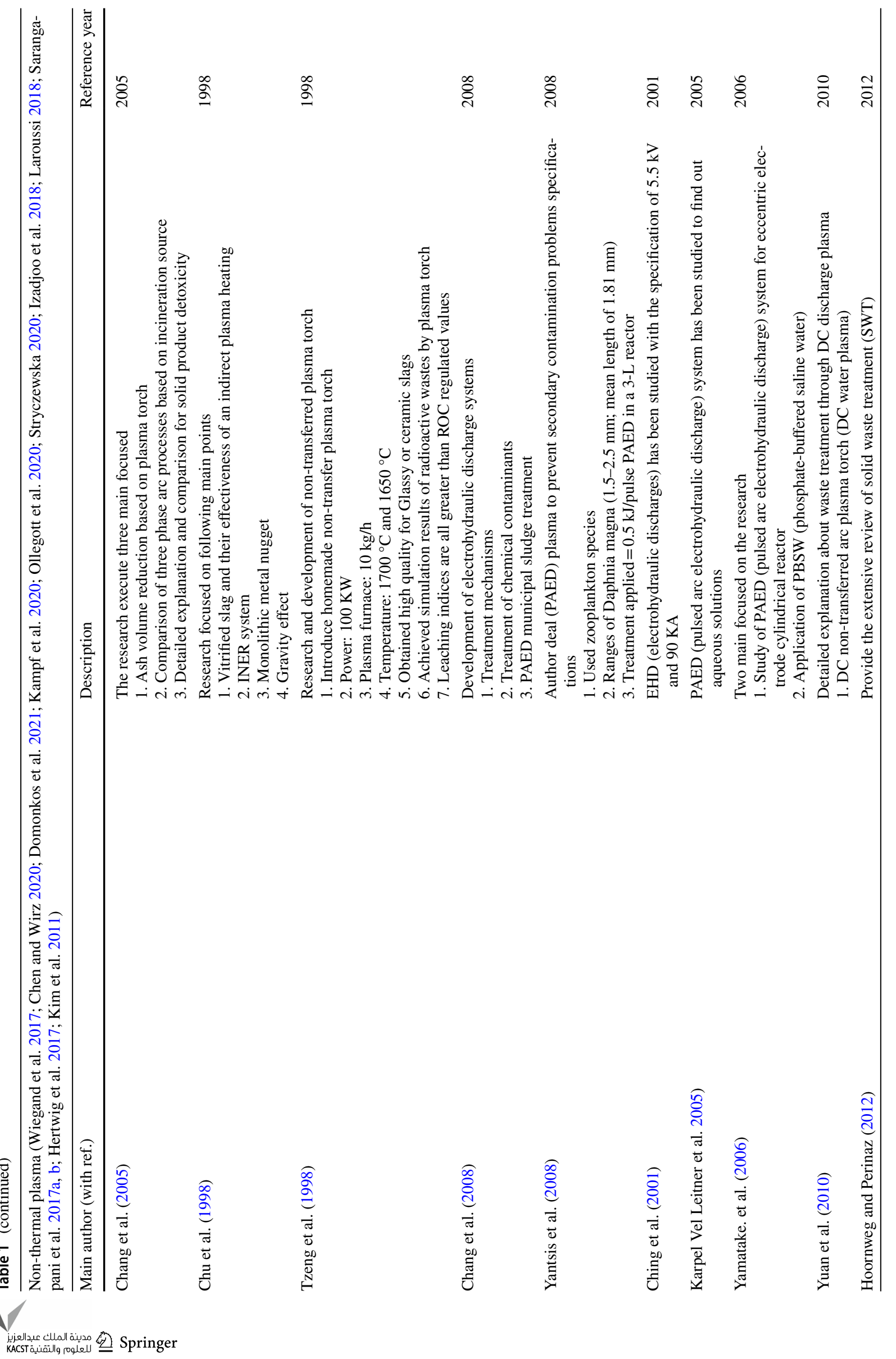




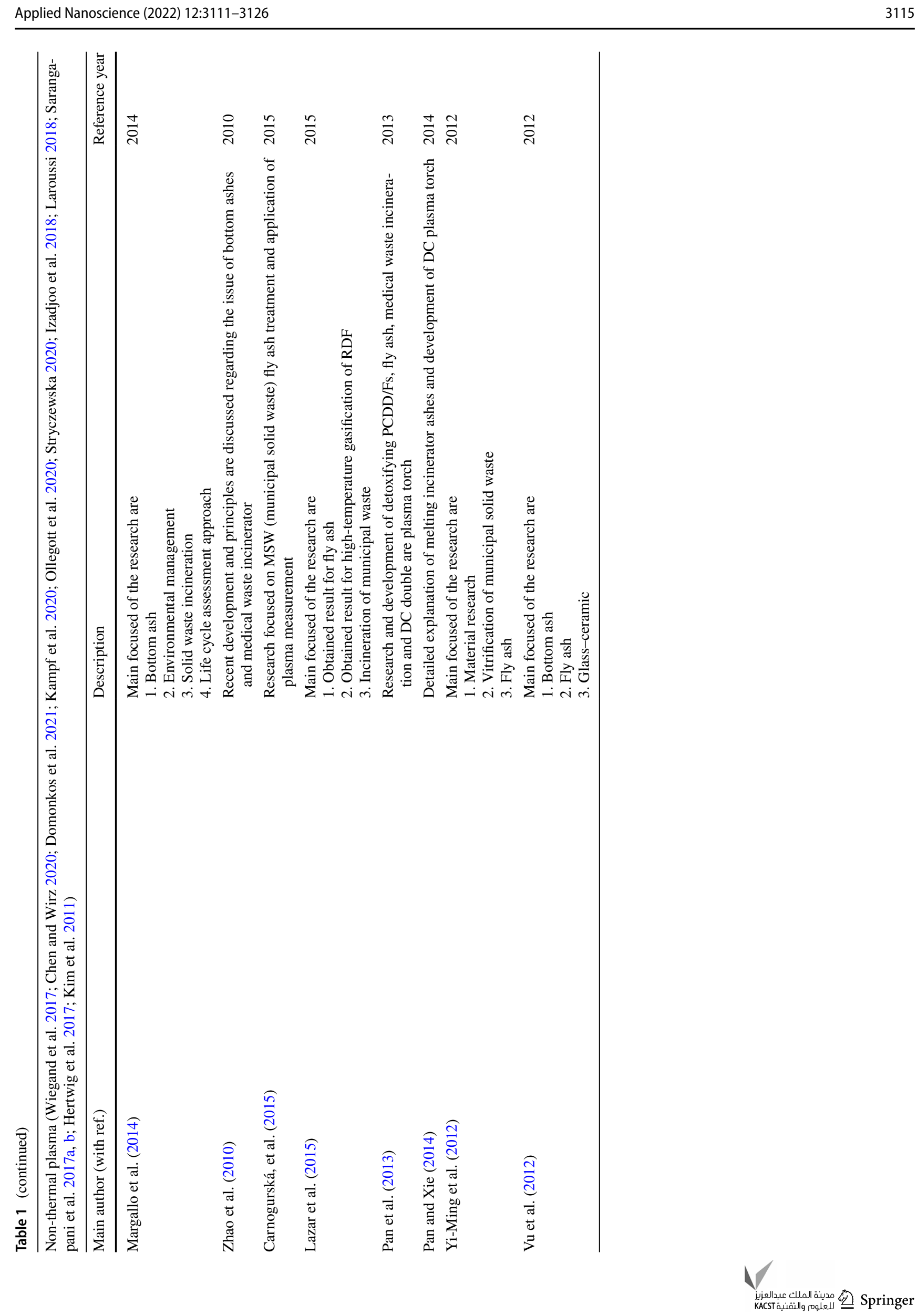


bio-medical applications. In addition, it is aim to present basic principles and experimental procedure to identify the pros and cons of thermal or non-thermal plasma in view of solid waste treatment processes and bio-medical issues.

\section{Concept of plasma}

In nature, the fourth state of matter is termed as plasma which is a combination of electron, ions and neutral particles. Plasma can be generated by flowing a current through the gas and this electrical breakdown produces ions, excited species, atoms and photons (by the collision of charge carrier and the gas molecules) (Boulos et al. 1994). Plasma is an electrical conductor which is formed by number of gases such as argon, nitrogen hydrogen, steam, helium, air oxygen, $\mathrm{CO}$, and $\mathrm{CO}_{2}$ (Moustakas et al. 2005). Therefore, for plasma generation, we commonly select Argon and nitrogen gas (Mabrouk et al. 2012). Plasma's are classified in terms of atmospheric pressure and low pressure. These are types of plasma, which are characterized by pressure, temperature and electron densities. Thermal and non-thermal plasma are two groups of atmospheric pressure plasma as presented in Table 2. Thermal plasma can be formed by flames, electric sparks and atmospheric arcs. It described by proximate equality between neutrals, ions and electrons. Its application includes waste material treatment, municipal waste, material processing, microwave devices, plasma torches, process nuclear waste, medical waste, etc. In non-thermal plasma, ions thermal motion, pressure force and magnetic force are not considered. Instead, electric force is required to exert the particles. Some of the examples includes discharge of flow in fluorescent tubes and in earth ionosphere. Treatment of biological tissues and polymers are application of nonthermal plasma.

\section{Thermal plasma}

\section{Development of plasma torches}

When the passing flowing gas through an electric arc and producing plasma; this type of device is called plasma torch. The optimal operating power of the plasma torches ranges from few hundred watts to several $100 \mathrm{~kW}$.

\section{Components of plasma torch}

The component of the plasma torch is such that the cathode terminal of plasma torch is connected to negative power supply of the torch. It shaped like thin pointed rods but some torches have flat-ended shapes as well. The anode terminal of the torch is shaped like a disc, ring, tube or of nozzle
Table 2 Grouping of plasma types (Chen 1974; Chang 2006, 2009)

\begin{tabular}{|c|c|c|}
\hline Plasma type & State & Example \\
\hline $\begin{array}{l}\text { Thermal plasma } \\
\text { (quasi-equilibrium) }\end{array}$ & $\begin{array}{l}T_{\text {electron }} \approx T_{\text {ion }} \approx T_{\text {gas }} \leq 10^{4} \text { to } \\
10^{8} \mathrm{~K} \text { nelements } \geq 10^{22} \text { to } \\
10^{28} \mathrm{~m}^{-3}\end{array}$ & $\begin{array}{l}\text { 1. Solid } \\
\text { and liquid } \\
\text { waste treat- } \\
\text { ments } \\
\text { 2. Material } \\
\text { processing } \\
\text { 3. Micro- } \\
\text { wave } \\
\text { devices } \\
\text { 4. Coat- } \\
\text { ing and } \\
\text { ceramic } \\
\text { processing } \\
\text { 5. Cutting } \\
\text { 6. Welding }\end{array}$ \\
\hline $\begin{array}{l}\text { Non-thermal plasma } \\
\text { (non-equilibrium) }\end{array}$ & $\begin{array}{l}T_{\text {electron }}>>T_{\text {ion }} \approx T_{\text {gas }}=300 \\
\text { to } 10^{3} \mathrm{~K} \text { nelements } \approx \\
10^{20}-10^{21} \mathrm{~m}^{-3}\end{array}$ & $\begin{array}{l}\text { 1. Air pollu- } \\
\text { tion control } \\
\text { 2. Polymer } \\
\text { coating and } \\
\text { treatments } \\
\text { 3. Wound } \\
\text { healing } \\
\text { and cancer } \\
\text { treatment } \\
\text { 4. Biological } \\
\text { cells and } \\
\text { tissues } \\
\text { 5. Bio- } \\
\text { decontami- } \\
\text { nation } \\
\text { 6. Cold } \\
\text { plasma } \\
\text { treatment }\end{array}$ \\
\hline
\end{tabular}

type and can be mounted inside/outside of the torch. Flow pattern of the gas is an important parameter in generating plasma and controls various parameters including jet length of plasma, maximum temperature and cooling of electrodes. Shape of the torch is such that both anode and cathode are fused together in one housing and plasma is limited to flow in one direction. The material used for the construction of plasma torch can be of different materials.

\section{Types and classifications of plasma torch}

There are three types of torch: (1) radio frequency torch, (2) alternating current torch, (3) direct current torch. Plasma torches are classified as transferred arc plasma torch and non-transferred arc plasma torch as illustrated in Fig. 1. In transferred arc plasma torch, both cathode and anode are placed in specific distance and anode considered as a work piece. Whereas, in the case of non-transferred arc type torch (plasma), distance between cathode and anode is in few millimeters (Venkatramani 2002; Zhukov 2007). Generally, 

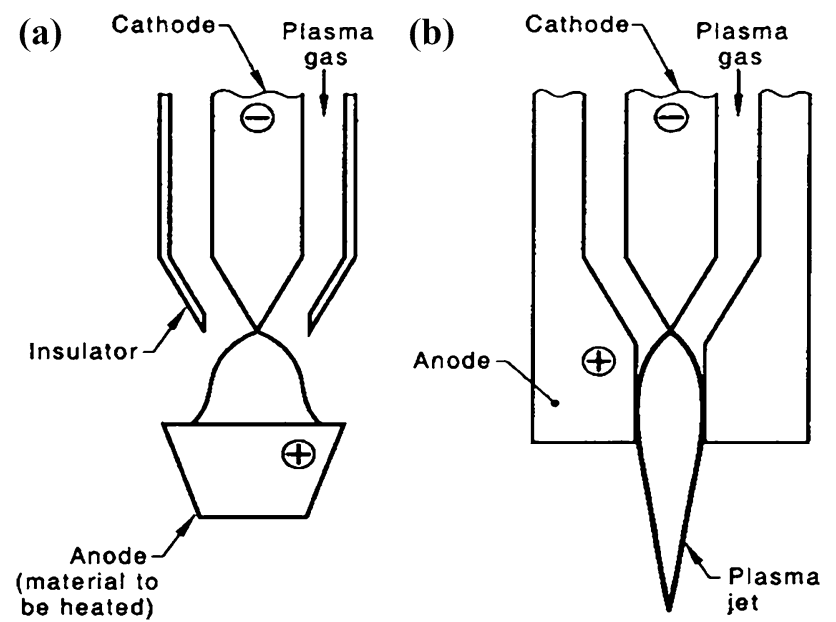

Fig. 1 Schematic diagram of direct current (DC) thermal plasma torches (Murphy 1999): a transferred arc, b non-transferred arc (copyright permission)

nitrogen, argon, hydrogen and oxygen gases are used in such type of plasma torches.

\section{Solid waste treatment by thermal plasma}

The demand of plasma torches is increasing enormously due to its potential benefits which includes, alternatives to fossil fuels, more reliable, cost-effective and to provide small capacity plants. This feature helps in the constructions of mega project more economical. Plasma torches also support zero carbon emission, because gas flow rate in torches are much smaller than conventional heating systems. Many advanced countries are working to build up the setup for plasma research so to potentially reduces the environmental issues (Inaba and Iwao 2000; Chang 2001; Chang and Mahant 1994; Donaldson et al. 1991), for example, municipal wastes (Chang and Mahant 1994; Donaldson et al. 1991), discard tires (Chang et al. 1996), toxic and hazardous materials (Chu et al. 1998), chemicals (Chang and Mahant 1994; Donaldson et al. 1991) or contaminated waste (Tzeng et al. 1998; Yasui et al. 1998) and from steel industries, power plants etc.

Generally, the procedure for waste treatment plants can be describe in three ways (Chang 2001, 2009) as,

1. To gather all solid and liquid discharges even in gaseous forms from water ponds or open air with dilution under specific limit.

2. To help producing building materials, agricultural usage and bio-products from conversion of wastes.

3. Transformation of solid wastes to non-toxic products such as carbon dioxide, nitrogen gas, oxygen to water ponds, landfills and air.
Among several methods, thermal plasma is considered to be the most viable and effective method for solid waste treatment, because in this process, only small amount of toxic products released. Generally, industrial, medical, military and municipality wastes can be treated through the plasma reactors (Inaba and Iwao 2000; Chang 2001; Chang et al. 2005, 1997; Chu et al. 1998; Tzeng et al. 1998; Yasui et al. 1998; Jimbo et al. 1995). However, large volume of industrial and municipal wastes can be treated using incinerator-plasma ash melting system (Chang 2009). In further sections, we will provide the details of thermal plasma applications which dictates the suitability of municipal solid waste treatment, hazardous waste, steel making and plasma jet injection treatment.

\section{Municipal solid waste treatment}

The municipal solid waste is an important role in our daily life and it is unavoidable product, the flow diagram of waste management system is depicted in Fig. 2. As we understand, the population of the world increasing day by day and we are facing the problem to store municipal waste. Therefore, we need to have the treatment to store this municipal waste. For this purpose, we used the term named as 'municipal solid waste (MSW) treatment'. The MSW treatment is able to recycle waste material and convert it into useable product (Agamuthu et al. 2009). Now a days, major globally environmental problem is because of MSW, and this is very general in developing countries. Due to the heterogeneous nature, it emerges as challenging problem. MSW is directly linked to our community, because it may include hazardous and non-hazardous waste material. This problem is also challengeable for rural and developing countries due to low socio-economic level of population and lack of awareness. Domestic solid waste, commercial solid waste and industrial solid waste are the main sources which are generated by municipal solid waste (Chandler 1997). Number of studies have been performed on this issue of MSW treatment, some of them are listed as follows:

- Nam and Capereda (2015) introduced RSM (response surface methodology) technique to understand effects of process conditions and compositions of biomass changing.

- Nam et al. (2017) described the advantage of dairy manure mixed with sand and bedding for gasification.

- Nam et al. (2015) investigated three bench-scale auger, batch and fluidized bed reactors through rice straw in specific temperature.

- Arazo et al. (2017) investigated fluidized bed reactor and used optimization technique for bio-oil through fast pyrolysis. 


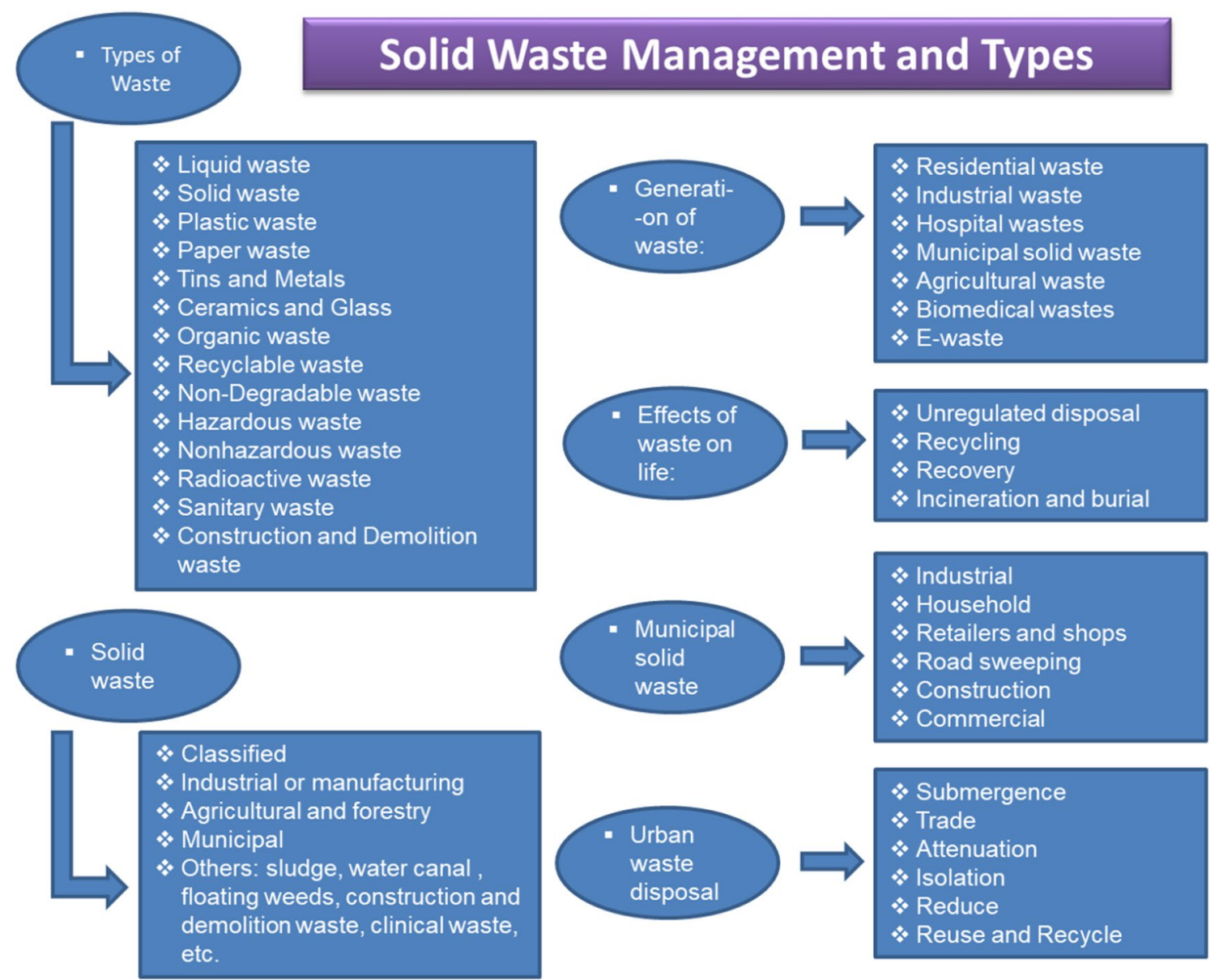

Fig. 2 Solid waste management and their types

- Meng et al. (2015) introduced two methods and provide comparison of physicochemical and compositional properties of aged bio-oils.

- Wang et al. (2016) doing research on municipal wastewater especially targeted to hydrothermal liquefaction of microalgae and metal testing with specific pressure and temperature.

- Omoriyekomwan et al. (2016) investigated catalytic fixed-bed and microwave pyrolysis of palm kernel shell through carbon, lignite char and microwave receptors.

- Yuan et al. (2015) introduced the major methods for processing municipal solid waste (MSW) harmlessly and they reputed the effectiveness of torrefaction for removing moisture and improving material properties.

- Kambo and Dutta (2015) provide the comparative review for biochar and hydrochar, this review explain the detail analysis of production, physic-chemical properties and applications.

- Mashayekh-Salehi and Moussavi (2015) investigated pharmaceutical compounds in aqueous solution through material research.
Thermal plasma plant assisted by ash melting volume reduction method was developed and commercialized at Matsuyama city in Japan with a capability to treat 52 tons of ashes/day (Chang 2009). In the schematic of plasma ash melting system as illustrated in Fig. 3, it can be observed that two DC 1.5 MW plasma torches are used as heat source with upper and lower columns. The torches are operated from 0.4 to $1.3 \mathrm{MW}$ which is generated by waste incinerations depending upon the ash volume required to treat. In this case, no electricity is required from external source. A typical plasma melting temperature ranges from 1100 to $1700{ }^{\circ} \mathrm{C}$ depending upon the plasma operating power source (Chang 2009).

\section{Hazardous waste: health care treatment}

The wastes from healthcare centers are usually classified into general waste and hazardous wastes. Hazardous needs to be handle in special way but general waste does not need to handle with intense care. Medical usage includes anatomical wastes (tissues and organs), blood and fluids, discarded 


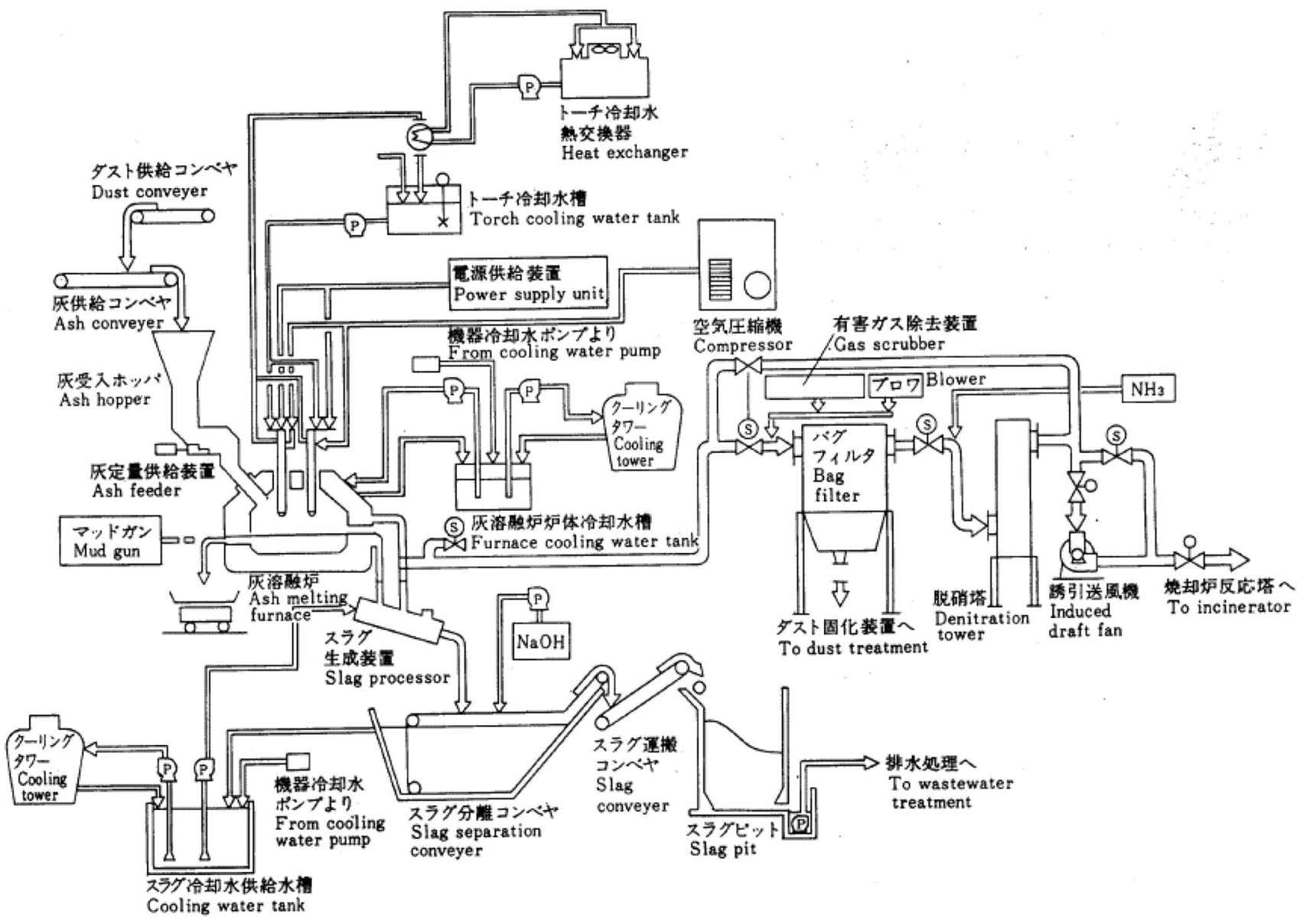

Fig. 3 Plasma ash melting system in Matsuyama (Chang 2009) (with copy right permission)

medicines, pathological and highly infectious wastes. For the medical purposes, the thermal plasma contains ultra-violet radiations and high temperatures, which can kill bacteria and micro-organisms. In addition, drug structure and active ingredients which constitutes only a small fraction of actual mass e.g., cytotastic and cytotoxic drugs can be destroy with thermal plasma (Nema and Ganeshprasad 2002). In hospital incinerates, usually plasma furnace used to treat bottom ash through coal fired power plant (see Table 3). Number of studies are reported in well-known scientific platforms such as Gensburg et al. (2009) addressed the major incident of love canal residents, $\mathrm{Li}$ et al. (2015) described the life cycle assessment and hazardous waste in Eastern China, Saleh (2012) demonstrated the phytoremediation efficiency of live floating plant, Eskander and Saleh (2012) provide the detail analysis of cement mortar-degraded spinney waste and radioactive waste, Eskander et al. (2013) investigated liquid scintillator waste, leachant type and leaching temperature.

For the hazardous waste, the republic of Korea tested the performance of plasma torch system for the treatment of medical wastes. They used two types of torches in treatment denoted by N1 and N2 (see Table 4) (Park et al. 2005). The temperature exceeds to $1500{ }^{\circ} \mathrm{C}$ when $\mathrm{N} 2$ is in operation and slag is flowed out and gathered into the collector region. The
Table 3 Hospital incineration and chemical analysis (Cedzynska et al. 1999) (with copyright permission)

\begin{tabular}{llllllllllll}
\hline Oxide & $\mathrm{SiO}_{2}$ & $\mathrm{Al}_{2} \mathrm{O}_{3}$ & $\mathrm{Fe}_{2} \mathrm{O}_{3}$ & $\mathrm{Mn}_{3} \mathrm{O}_{4}$ & $\mathrm{TiO}_{2}$ & $\mathrm{CaO}$ & $\mathrm{Na}_{2} \mathrm{O}$ & $\mathrm{MgO}$ & $\mathrm{K}_{2} \mathrm{O}$ & $\mathrm{P}_{2} \mathrm{O}_{5}$ & $\mathrm{SO}_{3}$ \\
\hline $\begin{array}{l}\text { Hospital } \\
\text { incinera- } \\
\text { tor bot- } \\
\text { tom ash }\end{array}$ & 47.35 & 3.05 & 7.35 & $\mathrm{a}$ & $\mathrm{a}$ & 16.25 & $\mathrm{a}$ & 2.45 & $\mathrm{a}$ & 0.30 & 0.48 \\
$\begin{array}{c}\text { Coal power } \\
\text { plant fly } \\
\text { ash }\end{array}$ & 50.02 & 23.20 & 9.25 & 0.15 & 0.96 & 4.08 & 0.96 & 2.48 & 3.40 & 0.32 & 0.52 \\
\hline
\end{tabular}


Table 4 Plasma torch system built in Korea for the treatment of medical wastes (Park et al. 2005) (with copy right permission)

\begin{tabular}{lll}
\hline Parameters & N1 plasma torch & N2 plasma torch \\
\hline Power & $40-45 \mathrm{~kW}$ & $65-85 \mathrm{~kW}$ \\
Airflow & $4-6 \mathrm{~g} / \mathrm{s}$ & $7-9 \mathrm{~g} / \mathrm{s}$ \\
$\begin{array}{l}\text { Plasma jet tempera- } \\
\quad 3.0-4.0 \mathrm{~K}\end{array}$ & $2.5-4.0 \mathrm{~K}$ \\
\hline
\end{tabular}

composition of slag dictates that it is chemically resistive and vitreous and not contains any organic components with a density of 2.6-2.8 K kg/m³ (Park et al. 2005).

\section{Steelmaking}

Comparatively large amount of wastes in the form of dust as well as metals such as iron, lead, zinc, chromium, nickel, molybdenum is recovered from steel manufacturing industries. Table 5 presents annual global solid waste from steel industry. These metal wastes are sometime extremely hard but are economical and is possible to extract and recycle them. Furthermore, these wastes are hazardous due to the leachability of hazardous components.

\section{Treatment through plasma jet injection}

Organic contaminant present in aqueous solution creates many problems in some industries such as paper, pulp and aluminum. Therefore, development of treatment method for liquid solution is very important. Considerable numbers of efforts and techniques are made to find an effective solution for treatment of these contaminants in liquids. Among them, includes various types of plasma and incineration. In Fig. 4, the plasma treatment of aqueous solutions by experimental reactor is shown. The treatment contains plasma which transfer high electrical energy into liquid phase and generates highly active compounds such as ozone, hydroxyl radicals, hydrogen peroxide, etc. (Munholand et al. 2006; Armstrong and Soucy 2007; Boudesocque et al. 2007; Safa and Soucy 2014; Samokhin et al. 2010; Fortin et al. 2000; Yargeau et al. 2004; Soucy et al. 2006). Hafnium doped

Table 5 Annually worldwide solid waste from steel industry (Ye et al. 2003) (with copy right permission)

\begin{tabular}{clllll}
\hline $\begin{array}{l}\text { Major } \\
\text { concerns }\end{array}$ & $\begin{array}{l}\text { Free } \\
\text { lime, } \\
\text { heavy } \\
\text { metals }\end{array}$ & $\begin{array}{l}\text { Leaching } \\
\text { of heavy } \\
\text { metals }\end{array}$ & $\begin{array}{l}\text { Too low } \\
\text { Zn for } \\
\text { recovery }\end{array}$ & $\begin{array}{l}\text { Too high } \\
\text { Zn for } \\
\text { recycling }\end{array}$ & $\begin{array}{l}\text { Hazardous } \\
\text { wastes }\end{array}$ \\
\hline $\begin{array}{c}\text { World } \\
\text { (Mtons) }\end{array}$ & BOF slag & EAF slag & BOF dust & - & EAF dust \\
& 90 & 25 & 15 & - & 4 \\
\hline
\end{tabular}

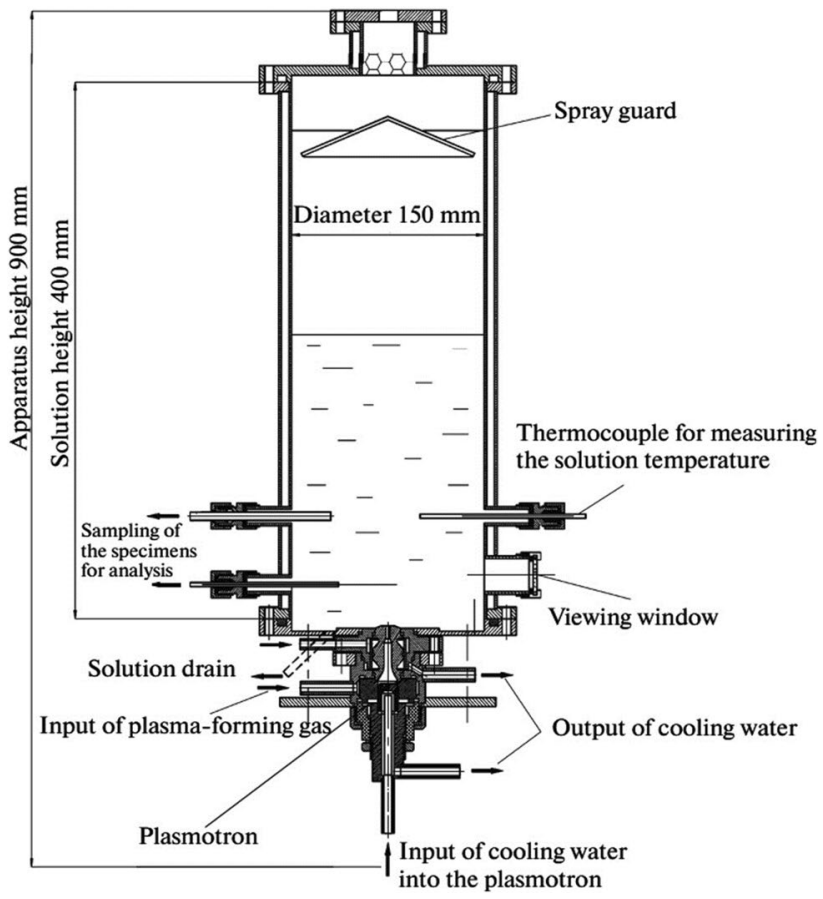

Fig. 4 Plasma treatment of aqueous solutions by experimental reactor (Samokhin et al. 2010) (with copyright permission)

copper rod material is also being used for solving the cathode erosion problem in oxidative medium (Yuan et al. 2010).

\section{Non-thermal plasma}

\section{Treatment through dielectric barrier discharge (DBD) plasma}

Generally, all plasmas defined into two major categories in terms of electric density or temperature, which we called thermal or non-thermal plasmas. Thermal plasma (arc discharges, torches or radio frequency) is nearly fully ionized while non-thermal plasma (biomedical applications: plasma jets, coronal discharge plasma sources, DBD plasma sources) is only partially ionized. In thermal plasma (hot plasma: $T_{\mathrm{e}} \sim T_{\text {gas }}$, plasma torches or high pressure discharges), which approaches a state of local thermodynamics equilibrium, while motion of ions can be ignored in nonthermal plasma (cold plasma: $T_{\mathrm{e}}>>T_{\mathrm{gas}}$, low-pressure discharges or dielectric barrier discharges). Etching, chemical vapor deposition, plasma polymerization, surface structuring are example of plasma technology, which are interrelated with electronics, semiconductor industry and materials science (Domonkos et al. 2018, 2016, 2020; Ticha et al. 2020; Steinerova et al. 2021). This technology has a long history but currently cold atmospheric pressure plasma (CAPP) has an active role especially for industrial sectors. Usually, 
CAPP is suitable for surface treatment such as metal, glass, polymer, etc. (Cvelbar et al. 2018; Talviste et al. 2019; Medvecka et al. 2020; Thomas et al. 2019). Treatment through cold plasma are already used in medical issues and laboratory equipment such as bacteria, fungi, viruses, biofilms, surgical instruments, pharmaceutical devices, implants, dialysis tubes, glassware, plastic tubes, pipette tips, beds, floors, etc. (see Fig. 5). Direct and contact through source of micro-organisms are the two ways for contamination and the process in illustrated in Fig. 6. For example, a patient

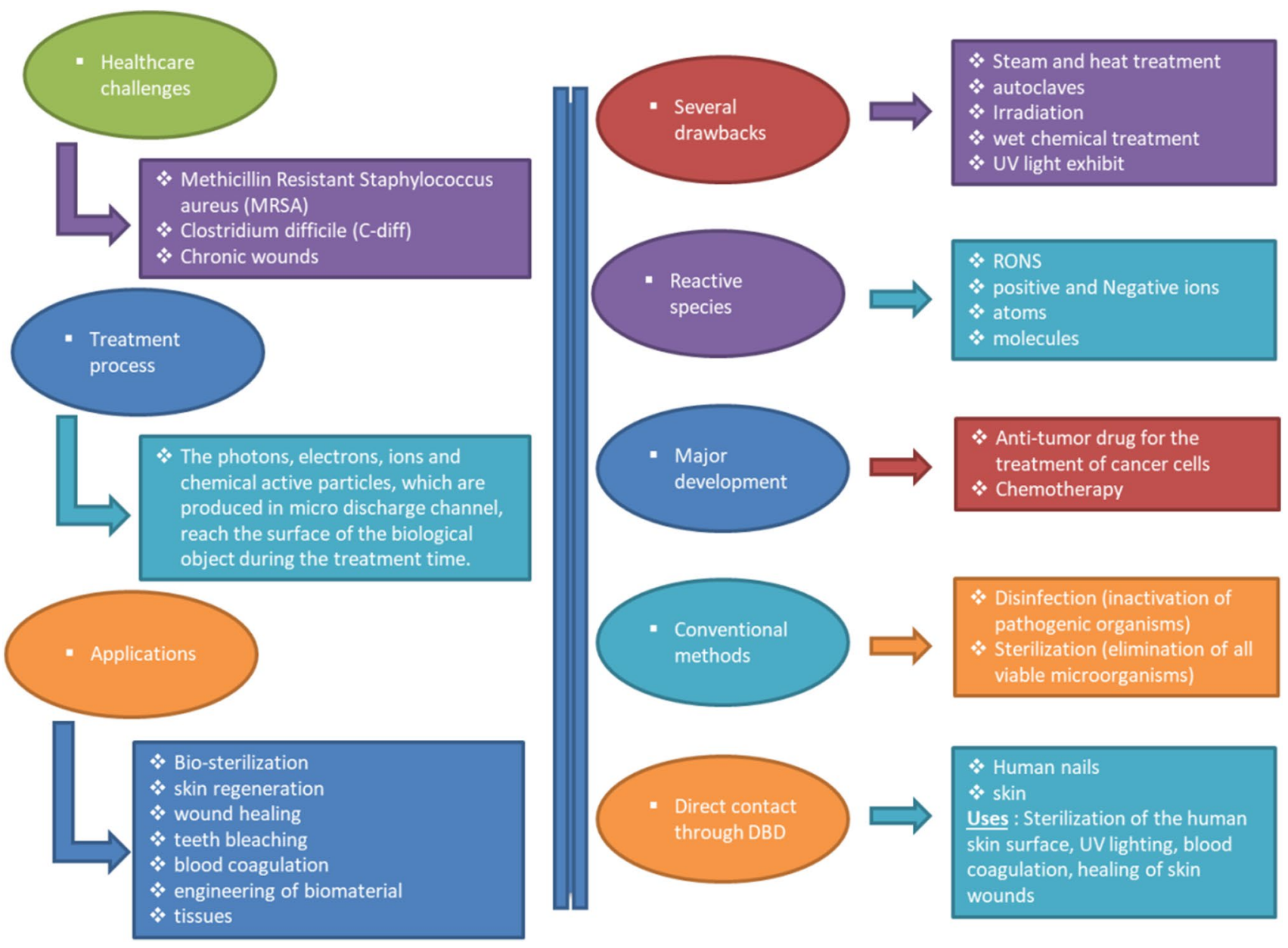

Fig. 5 Flowchart shown the schemes and characterization of dielectric barrier pulsed discharge plasma for bio-medical applications

Fig. 6 Contamination process (Laroussi et al. 2012)

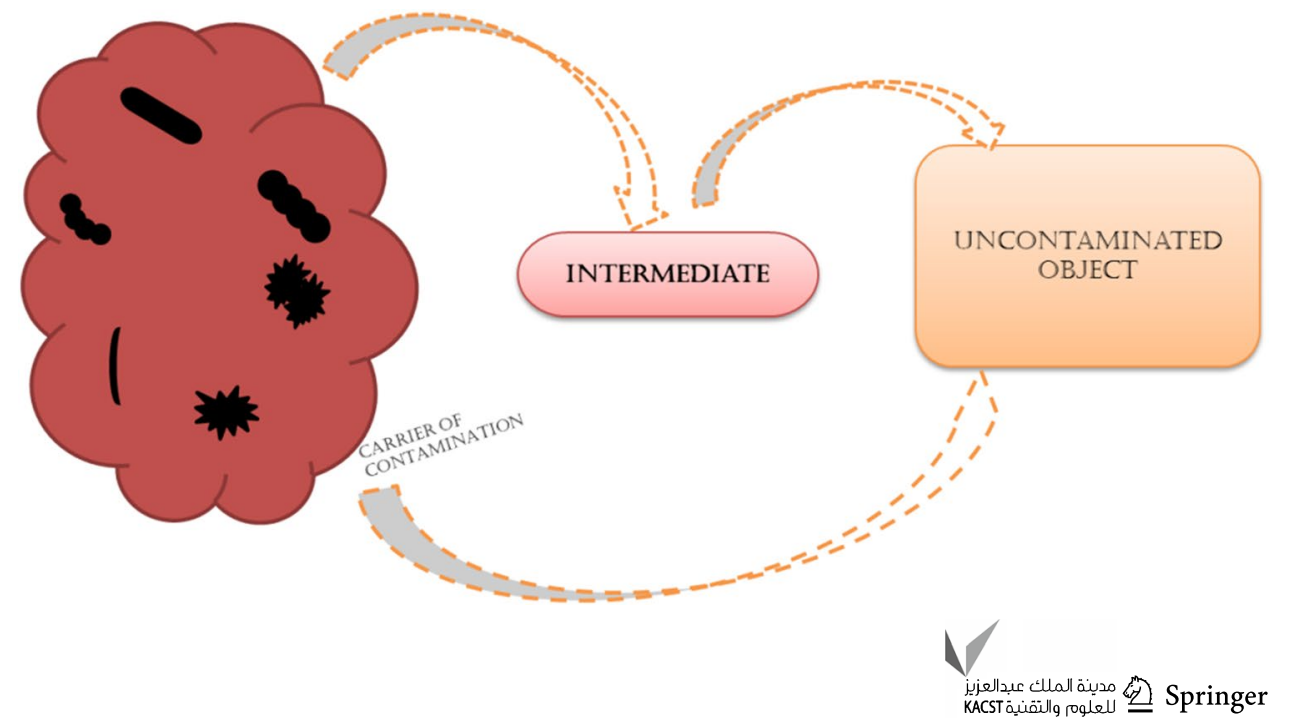


sneezes into his hand and then shakes hand with other people or touch the door handle or eat something else. This is a way to transfer viral particles to other by formation of biofilm (Fig. 7). Some past research are depicted as follows:

- Laroussi (2009) tried to solve some fundamental questions which are directly related to cold plasma treatment and for medicines.

- Laroussi (1996) developed a new approach based on various plasma technologies.

- Kelly-Wintenberg et al. (1998) and research team studied the method of one atmosphere uniform glow discharge plasma and make it possible to provide for antimicrobial active species to surfaces.

- Herrmann et al. (1999) and team members studied atmospheric pressure plasma jet and high velocity effluent stream of highly reactive chemical species.

- Laroussi et al. (2000) found the effective agents for biological decontamination/sterilization through non-thermal gaseous discharge.

- Laroussi (2002) prepared the review for non-thermal plasma decontamination and addressed some inline topics such as biological and germicidal effects of atmospheric pressure.

- Laroussi (1999) published the US Patent in the field of plasma glow discharge.

- Shekhter et al. (1998) provide the detail of plasma chemical method and its utilization for health issues.

- Stoffels et al. (2002) and research team are working on non-plasma source. They address the utilization of this source especially for biomaterials treatment.

- Woloszko et al. (2002) and research team are working on saline solutions and they reported sodium chloride and barium chloride saline solutions.

\section{Plasmonic material}

In this review report, we reported a newly introduced method of plasmonic nano-material, an interesting material for diverse applications including energy sectors, solar/fuel cells and sensor, solid waste, bio-medical issues and laboratory equipment. The results of this method are illustrated in Fig. 8 which successfully demonstrated the chemical detection (Khan et al. 2020). Previously, in the literature, this method was used in vacuum, while in the reported data, a quite new approach of flowing gas is being adopted to test it at atmospheric pressure. This approach seems to facilitate nanofabrication on industrial scale.

Conventional method is used since several decades and it is consider a versatile technique but it does not incorporate for industrial application. Therefore, traditional method is suitable for industrial application such as vacuum requirements, limited area deposition, coating of irregular objects and long deposition time (Khan et al. 2020; Eason 2007; Mirza et al. 2014; Donnelly et al. 2006; Mihailescu and Caricato 2018).

Some of the applications of atmospheric pressure dielectric barrier discharge (DBD) plasma is as follows:

- Plasmonic active nanoparticle (NP)-coated surfaces for surface enhanced Raman spectroscopy (SERS) application for chemical detection.

- Enhanced detection in LIBS.

- Surface modification.

- Mechanisms can be extended to fast switching.

- Nanomaterial fabrication using DBD plasma stream.

- Antibacterial silver coating of surgical devices.

- Surface etching/modification.
Fig. 7 Formation of biofilm and stages (Laroussi et al. 2012)
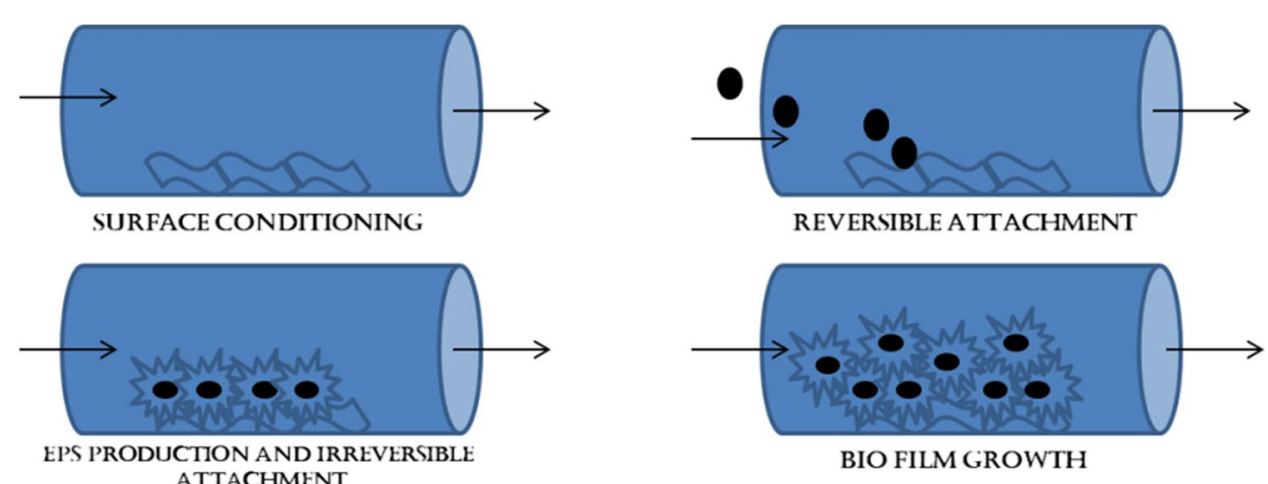

BIO FILM GROWTH

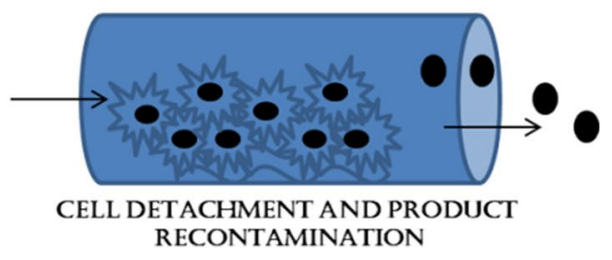




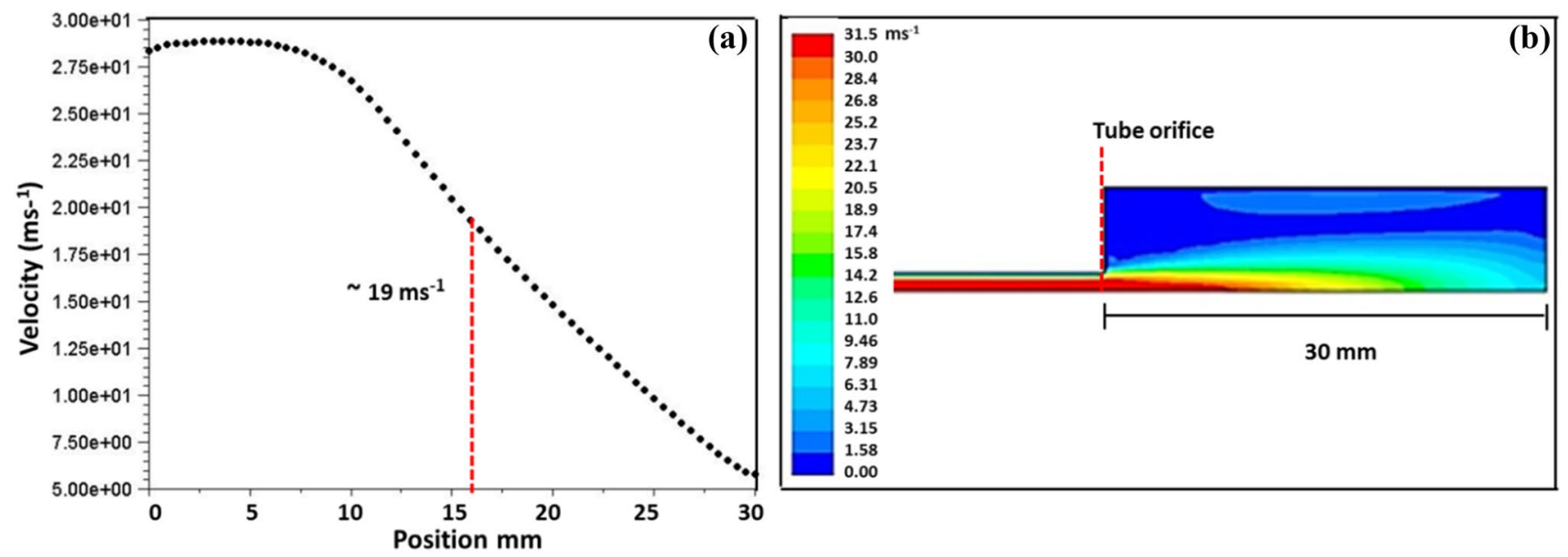

Fig. 8 a Velocity magnitude contour, b velocity profile of argon flow at 7 L/min (Donnelly et al. 2006)

This is new development and is a great contribution in the field of nanotechnology; facilitates the fabrication of nano-material for energy applications, solid waste treatment through non-thermal plasma, energy devices and open new rooms for further research.

\section{Conclusion}

In this review, research is successfully define thermal plasma treatment and non-thermal plasma with its utilities in nano-scale high-tech plasmonic materials. We have elaborated globally analysis of solid waste treatment through thermal plasma and dielectric barrier discharge (DBD) plasma research. For this purpose, we have defined the conceptual detail of arc plasma torches (transferred and non-transferred torches) and provided the short review of our in-depth conducted research for solid waste treatment through thermal plasma such as solid waste, healthcare, steelmaking, and treatment through plasma jet injection. Furthermore, a short review for the treatment through dielectric barrier discharge (DBD) plasma, and plasmonic material are included. In the focus of deep analysis, treating solid waste issues through thermal plasma is the best choice and the application of non-thermal plasma such as DBD is the most useful and latest approach for plasmonic material.

Acknowledgements The research team showed their gratitude and sincere appreciation to Pakistan Tokamak Plasma Research Institute (PTPRI) Initiative for funding and supported this research.

\section{Declarations}

Conflict of interest All authors declare no conflict of interest.

\section{References}

Agamuthu P, Khidzir KM, Hamid FS (2009) Drivers of sustainable waste management in Asia. Waste Manag Res 27:625. https:// doi.org/10.1177/0734242X09103191

Arazo RO, Genuino DAD, de Luna MDG, Capareda SC (2017) Bio-oil production from dry sewage sludge by fast pyrolysis in an electrically-heated fluidized bed reactor. Sustain Environ Res 27:7-14

Armstrong L, Soucy G (2007) Oxidation of Bayer liquor organics with submerged plasma. Light Met 2007:145-149

Boudesocque N, Lemort F, Lafon C, Girold C, Meillot E, Vandensteendam C, Baronnet JM (2007) Decontamination and gasification of aqueous organic waste by submerged thermal plasma. In: 26th annual international conference on incineration and thermal treatment technologies. IT3

Boulos MI, Fauchais P, Pfender E (1994) Thermal plasmas: fundamentals and applications. Plenum Press, New York, pp 1-4

Carnogurska M et al (2015) Measurement and evaluation of properties of MSW fly ash treated by plasma. Measurement 62:155-161

Cedzynska K, Kolacinski Z, Izydorczyk M, Sroczynski W (1999) Plasma vitrification of waste incinerator ashes. In: International ash utilization symposium, Centre for Applied Energy Research, University of Kentuky

Chandler AJ et al (1997) Municipal solid waste incinerator residues. Elsevier, Amsterdam

Chang JS (2001) Recent development of plasma pollution control technology: a critical review. Sci Technol Adv Mater 2:571-576

Chang JS (2006) Physics and chemistry of atmospheric plasmas (in Japanese). J Plasma Fusion Res 83(10):682-692

Chang JS (2008) Physics and chemistry of plasma pollution control technology. Plasma Sources Sci Technol 17:045004

Chang JS (2009) Thermal plasma solid waste and water treatments: a critical review. Int J Plasma Environ Sci Technol 3(2):67-84

Chang JS, Mahant P (1994) A status report on environmental applications of thermal plasma technology. In: Mahant P, Pickles C, Lu WK (eds) Resource conservation and environmental technologies in metallurgical industries. The CIM Press, Toronto, pp 119-132

Chang JS, Gu BW, Looy PC, Chu FY, Simpson CJ (1996) Thermal plasma pyrolysis of used old tires for production of syngas. $\mathrm{J}$ Environ Sci Health Part A Toxic Hazard Subst Environ Eng 31:1781-1799 
Chang JS, Jimbo H, Kikuchi T, Amemiya T (1997) Fly ash particles generated by a plasma municipal waste incinerator ash volume reduction system. J Aerosol Sci 28:S551-S552

Chang JS, Ara M, Urashima K, Jimbo H, Oinuma K (2005) Comparisons of solid by-products generated from thermal plasma incineration ash melting systems by plasma torch and three-phase submerged arc processes. J Adv Oxid Technol 8:59-64

Chang JS, Dickson S, Guo Y, Urashima K, Emelko MB (2008) Electrohydraulic discharge direct plasma water treatment in advanced plasma technology. In: d'Agostino R, Favia P, Kawai Y, Ikegami H, Sato N, Arefi-Khonsari F (eds) Advanced Plasma Technology, Ch. 21. Wiley, Hoboken

Chen F (1974) Introduction to plasma physics and controlled fusion, vol 1. Springer, Cham, pp 1-16

Chen Z, Wirz R (2020) Cold atmospheric plasma for COVID-19. Preprints, 2020040126

Ching WK, Colussi AJ, Sun HJ, Nealson KH, Hoffmann MR (2001) Escherichia coli disinfection by electrohydraulic discharges. Environ Sci Technol 35:4139-4144

Chu JP, Hwang IJ, Tzeng CC, Kuo YY, Yu YJ (1998) Characterization of vitrified slag from mixed medical waste surrogates treated by a thermal plasma system. J Hazard Mater 58:179-194

Cvelbar U, Walsh JL, Cernak M, De Vries HW, Reuter S, Belmonte T, Corbella C, Miron C, Hojnik N, Jurov A et al (2018) White paper on the future of plasma science and technology in plastics and textiles. Plasma Process Polym 16:1700228

Domonkos M, Izak T, Kromka A, Varga M (2016) Polymer-based nucleation for chemical vapour deposition of diamond. J Appl Polym Sci 133:133

Domonkos M, Izak T, Varga M, Potocky S, Demo P, Kromka A (2018) Diamond nucleation and growth on horizontally and vertically aligned Si substrates at low pressure in a linear antenna microwave plasma system. Diam Relat Mater 82:41-49

Domonkos M, Demo P, Kromka A (2020) Nanosphere lithography for structuring polycrystalline diamond films. Curr Comput-Aided Drug Des 10:118

Domonkos M, Techa P, Trejbal J, Demo P (2021) application of cold atmospheric pressure plasma technology in medicine. Agric Food Ind Appl Sci 11(11):4809

Donaldson AD, Apa RP, Eddy TL, Flinn JE (1991) Review of plasma destruction of hazardous mixed waste. In: 28th National heat transfer conference, vol 161, pp 41-51

Donnelly T, Doggett B, Lunney JG (2006) Pulsed laser deposition of nanostructured Ag films. Appl Surf Sci 252:4445-4448

Eason R (2007) Pulsed laser deposition of thin films: applications-led growth of functional materials. Wiley, New York

Eskander SB, Saleh HM (2012) Cement mortar-degraded spinney waste composite as a matrix for immobilizing some low and intermediate level radioactive wastes: consistency under frost attack. J Nucl Mater 420(1-3):491-496

Eskander SB, Bayoumi TA, Saleh HM (2013) Leaching behavior of cement-natural clay composite incorporating real spent radioactive liquid scintillator. Prog Nucl Energy 67:1-6

Fortin L, Soucy G, Kasireddy VK, Bernier JL (2000) Novel reactor for cyanide solution treatment. Can J Chem Eng 78(4):643-649

Gensburg LJ, Pantea C, Kielb C, Fitzgerald E, Stark A, Kim N (2009) Cancer incidence among former Love Canal residents. Environ Health Perspect 117(8):12651271

Herrmann HW, Henins I, Park J, Selwyn GS (1999) Decontamination of chemical and biological warfare (CBW) agents using an atmospheric pressure plasma jet. Phys Plasmas 6:2284-2289. https://doi.org/10.1063/1.873480

Hertwig C, Leslie A, Meneses N, Reineke K, Rauh C, Schluter O (2017) Inactivation of Salmonella enteritidis PT30 on the surface of unpeeled almonds by cold plasma. Innov Food Sci Emerg Technol 44:242-248
Hoornweg D, Perinaz B (2012) What a waste: a global review of solid waste management. Urban development series; knowledge papers no. 15. World Bank, Washington, DC. (C) World Bank

Inaba T, Iwao T (2000) Treatment of waste by DC arc discharge plasmas. IEEE Trans Dielectr Electr Insul 7:684-692

Izadjoo M, Zack S, Kim H, Skiba J (2018) Medical applications of cold atmospheric plasma: state of the science. J Wound Care 27:S4-S10

Jiang B, Zheng J, Qiu S, Wu M (2014) Review on electrical discharge plasma technology for wastewater remediation. Chem Eng J 236:348-368

Jimbo H, Saito M, Amemiya T, Kawase T (1995) Plasma ash volume reduction system (in Japanese). Ebara Jihou 168:89-95

Kambo HS, Dutta A (2015) A comparative review of biochar and hydrochar in terms of production, physico-chemical properties and applications. Renew Sustain Energ Rev 45:359-378

Kampf G, Todt D, Pfaender S, Steinmann E (2020) Persistence of coronaviruses on inanimate surfaces and their inactivation with biocidal agents. J Hosp Infect 104:246-251

Karpel Vel Leitner N, Syoen G, Romat H, Urashima K, Chang JS (2005) Generation of active entities by the pulsed arc electrohydraulic discharge system and application to removal of atrazine. Water Res 39:4705-4714

Kelly-Wintenberg K, Montie TC, Brickman C, Roth JR, Carr AK, Sorge K et al (1998) Room temperature sterilization of surfaces and fabrics with a one atmosphere uniform glow discharge plasma. J Indust Microboil Bio Technol 20:69-74. https://doi. org/10.1038/sj.jim.2900482

Kim B, Yun H, Jung S, Jung Y, Jung H, Choe W, Jo C (2011) Effect of atmospheric pressure plasma on inactivation of pathogens inoculated onto bacon using two different gas compositions. Food Microbiol 28:9-13

Laroussi M (1996) Sterilization of contaminated matter with an atmospheric pressure plasma. IEEE Trans Plasma Sci 24:1188-1191. https://doi.org/10.1109/27.533129

Laroussi M (1999) Sterilization of liquids using a plasma glow discharge. US Patent $\#$ 5,876,663

Laroussi M (2002) Non-thermal decontamination of biological media by atmospheric pressure plasmas: review, analysis, and prospects. IEEE Trans Plasma Sci 30:1409-1415. https://doi.org/10. 1109/TPS.2002.804220

Laroussi M (2009) Low temperature plasmas for medicine? IEEE Trans Plasma Sci 37:714. https://doi.org/10.1109/TPS.2009.2017267

Laroussi M (2018) Plasma medicine: a brief introduction. Plasma $1: 47-60$

Laroussi M, Alexeff I, Kang W (2000) Biological decontamination by nonthermal plasmas. IEEE Trans Plasma Sci 28:184-188. https:// doi.org/10.1109/27.842899

Laroussi M, Kong MG, Morfill G, Stolz W (2012) Applications of low-temperature gas plasmas in medicine and biology, plasma medicine. In: Laroussi M, Kong MG, Morfill G, Stolz W (eds) Chapter 5: contamination. Cambridge University Press, Cambridge, pp 99-114

Lazar M et al (2015) High-temperature gasification of RDF waste and melting of fly ash obtained from the incineration of municipal waste. Acta Polytechnica 55(1):1-6

Li W, Huang Q, Shengyong Lu, Hailong Wu, Li X, Yan J (2015) Life cycle assessment of the environmental impacts of typical industrial hazardous waste incineration in Eastern China. Aerosol Air Qual Res 15:242-251

Mabrouk M, Lemont F, Baronnet JM (2012) Incineration of radioactive organic liquid wastes by underwater thermal plasma. In: 12th high tech plasma processes conference. https://doi.org/10.1088/ $17426596 / 406 / 1 / 012002$

Margallo M, Aldaco R, Irabien A (2014) Environmental management of bottom ash from municipal solid waste incineration based on 
a life cycle assessment approach. Clean Technol Environ Policy 16(17):1319-1328

Mashayekh-Salehi A, Moussavi G (2015) Removal of acetaminophen from the contaminated water using adsorption onto carbon activated with $\mathrm{NH}_{4} \mathrm{Cl}$. Desalin Water Treat 57(27):1-13

Medvecka V, Kovacik D, Stupavska M, Roch T, Kromka A, Fajgar R, Zahoranova A, Cernak M (2020) Preparation and characterization of alumina submicron fibers by plasma assisted calcination. Ceram Int 46:22774-22780

Meng J, Moore A, Tilotta DC, Kelley SS, Adhikari S, Park S (2015) Thermal and storage stability of biooil from pyrolysis of torrefied wood. Energy Fuel 29:5117-5126

Mihailescu AN, Caricato AP (2018) Pulsed laser ablation: advances and applications in nanoparticles and thin films. CRC Press, Boca Raton

Mirza A, Connell GO, Wang JJ, Lunney JG (2014) Comparison of nanosecond and femtosecond pulsed laser deposition of silver nanoparticle films. Nanotechnology 25:265301

Moustakas K, Fatta D, Malamis S, Haralambous K, Loizidou M (2005) Demonstration plasma gasification/vitrification system for effective hazardous waste treatment. J Hazard Mater 123(1-3):120126. https://doi.org/10.1016/j.jhazmat.2005.03.038

Munholand L, Quintal P, Soucy GA (2006) hydrodynamic study of a plasma lift reactor. Can J Chem Eng 84(1):73-82

Murphy AB (1999) Plasma destruction of gaseous and liquid wastes. Ann N Y Acad Sci 891:106-123. https://doi.org/10.1111/j.17496632.1999.tb08758.x

Nam H, Capareda S (2015) Experimental investigation of torrefaction of two agricultural wastes of different composition using RSM (response surface methodology). Energy 91:507-516

Nam H, Capareda SC, Ashwath N, Kongkasawan J (2015) Experimental investigation of pyrolysis of rice straw using benchscale auger, batch and fluidized bed reactors. Energy 93(Part 2):2384-2394

Nam H, Maglinao AL Jr, Capareda SC (2017) Effective use of dairy manure mixed with sand bedding for gasification. Trans ASABE 60:5-16

Nema SK, Ganeshprasad KS (2002) Plasma pyrolysis of medical waste. Curr Sci 83:271-278

Ollegott K, Wirth P, Oberste-Beulmann C, Awakowicz P, Muhler M (2020) Fundamental properties and applications of dielectric barrier discharges in plasma-catalytic processes at atmospheric pressure. Chem Ing Tech 92:1542-1558

Omoriyekomwan JE, Tahmasebi A, Yu J (2016) Production of phenolrich bio-oil during catalytic fixedbed and microwave pyrolysis of palm kernel shell. Bioresour Technol 207:188-196

Pan X, Xie Z (2014) Characteristics of melting incinerator ashes using a direct current plasma torch. Environ Anal Toxicol 4(3):1-5

Pan X, Jianhua Y, Zhengmiao X (2013) Detoxifying PCDD/Fs and heavy metals in fly ash from medical waste incinerators with a DC double arc plasma torch. J Environ Sci 25(7):1362-1367

Park HS, Lee BJ, Kim SJ (2005) Medical waste treatment using plasma. J Ind Eng Chem 11:353-360

Safa S, Soucy G (2014) Liquid and solution treatment by thermal plasma: a review. Int J Environ Sci Technol 11:1165-1188

Saleh HM (2012) Water hyacinth for phytoremediation of radioactive waste simulate contaminated with cesium and cobalt radionuclides. Nucl Eng Des 242:425-432

Samokhin AV, Alekseev NV, Lainer YA, Tsvetkov YV (2010) Oxidation of organic impurities in production aluminate solutions under the effect of the thermal plasma jet. Russ J Non Ferr Met 51(3):217-221

Sarangapani C, OToole G, Cullen P, Bourke P (2017a) Atmospheric cold plasma dissipation efficiency of agrochemicals on blueberries. Innov Food Sci Emerg Technol 44:235-241
Sarangapani C, Devi RY, Thirumdas R, Trimukhe AM, Deshmukh RR, Annapure US (2017b) Physico-chemical properties of lowpressure plasma treated black gram. LWT Food Sci Technol 79:102-110

Shekhter AB, Kabisov RK, Pekshev AV, Kozlov NP, Perov YuL (1998) Experimental and clinical validation of plasma dynamic therapy of wounds with nitric oxide. Bull Exp Biol Med 126:829-834. https://doi.org/10.1007/BF02446923

Soucy G, Poirier G, Quintal P, Andrejack M (2006) Organic destruction in synthetic Bayer liqour by submerged thermal plasma. In: 17 th international symposium on ICSOBA combined with light metals, vol 33, pp 280-290

Steinerova M, Matejka R, Stepanovska J, Filova E, Stankova L, Rysova M, Martinova L, Dragounova H, Domonkos M, Artemenko A et al (2021) Human osteoblast-like SAOS-2 cells on submicronscale fibers coated with nanocrystalline diamond films. Mater Sci Eng C 121:111792

Stoffels E, Flikweert AJ, Stoffels WW, Kroesen GMW (2002) Plasma needle: anon-destructive atmospheric plasma source for fine surface treatment of biomaterials. Plasma Sources Sci Technol 11:383-388. https://doi.org/10.1088/0963-0252/11/4/304

Stryczewska HD (2020) Supply systems of non-thermal plasma reactors. Constr Rev Examples Appl Appl Sci 10:3242

Taj MK et al (2020) Silver nanoparticle films by flowing gas atmospheric pulsed laser deposition and application to surface-enhanced Raman spectroscopy. Int J Energy Res 44(14):11443-11452

Talviste R, Galmiz O, Stupavska M, Tucekova Z, Kaarna K, Kovacik D (2019) Effect of DCSBD plasma treatment on surface properties of thermally modified wood. Surf Interfaces 16:8-14

Thomas S, Mozetic M, Cvelbar U, Spatenka P, Praveen KM (2019) Non-thermal plasma technology for polymeric materials: applications in composites, nanostructured materials, and biomedical fields. Elsevier, Amsterdam (ISBN 978-0-12-813153-4)

Ticha P, Domonkos M, Demo P (2021) Fiber reinforced concrete: residual flexure strength enhancement using surface modified fibers. In: Special concrete and composites 2020: 17th international conference, vol 2322. AIP Publishing, College Park, pp 020030

Tzeng C-C, Kuo Y-Y, Huang T-F, Lin D-L, Yu Y-J (1998) Treatment of radioactive wastes by plasma incineration and vitrification for final disposal. J Hazard Mater 58:207-220

Urashima K, Chang JS (2000) Removal of volatile organic compounds from air streams and industrial flue gases by non- thermal plasma technology. IEEE Trans Dielectr Electr Insul 7:602-614

Venkatramani N (2002) Industrial plasma torches and applications. Curr Sci 83(3):254-262

$\mathrm{Vu}$ DH et al (2012) Glass-ceramic from mixtures of bottom ash and fly ash. Waste Manag 32:2306-2314

Wang Z, Adhikari S, Valdez P, Shakya R, Laird C (2016) Upgrading of hydrothermal liquefaction biocrude from algae grown in municipal wastewater. Fuel Process Technol 142:147-156

Wiegand C, Fink S, Hipler U-C, Beier O, Horn K, Pfuch A, Schimanski A, Grünler B (2017) Cold atmospheric pressure plasmas exhibit antimicrobial properties against critical bacteria and yeast species. J Wound Care 26:462-468

Woloszko K, Stalder KR, Brown IG (2002) Plasma characteristics of repetitively pulsed electrical discharges in saline solutions used for surgical procedures. IEEE Trans Plasma Sci 30:1376-1383. https://doi.org/10.1109/TPS.2002.801612

Yamatake A, Angeloni DM, Dickson SE, Emelko MB, Yasuoka K, Chang J-S (2006) Characteristics of pulsed arc electrohydraulic discharge for eccentric electrode cylindrical reactor using phosphate-buffered saline water. Jpn J Appl Phys 45:8298-8301

Yantsis SN, Chow-Fraser P, Li OL, Guo Y, Chang JS, Terui S, Watanabe K, Itoh M (2008) Zooplankton mortality in lake water treated

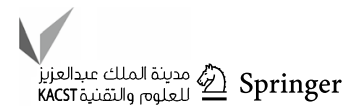


by pulsed arc electrohydraulic discharge plasma. Int J Plasma Environ Sci Technol 2(2):128-133

Yargeau V, Marcos B, Soucy GA (2004) New application of the severity factor kinetic model: thermal plasma treatment of black liquor. Can J Chem Eng 82(6):1209-1216

Yasui S, Adachi K, Amakawa T (1998) Influence of atmospheric gases on the treatment of miscellaneous solid wastes by plasma melting technology. Prog Nucl Energy 32:493-500

Ye GZ, Burstrom E, Kuhn M, Piret J (2003) Reduction of steel-making slags for recovery of valuable metals and oxide materials. Scand J Metall 32:7-14

Yi-Ming K, Kuo-Lin H, Chitsan L (2012) Metal behavior during vitrification of municipal solid waste incinerator fly ash. Aerosol Air Qual Res 12:1379-1385

Yuan M, Narengerile Watanabe T, Chang C (2010) DC water plasma at atmospheric pressure for the treatment of aqueous phenol. Environ Sci Technol 44(12):4710-4715
Yuan H, Wang Y, Kobayashi N, Zhao D, Xing S (2015) Study of fuel properties of torrefied municipal solid waste. Energy Fuel 29:4976-4980

Zhao LJ et al (2010) Typical pollutants in bottom ashes from a typical medical waste incinerator. J Hazard Mater 173(1-3):181-185

Zhukov MF (2007) Thermal plasma torches-design, characteristics, applications, ch 4. Cambridge Int Science Publishing, Switzerland, p 170

Publisher's Note Springer Nature remains neutral with regard to jurisdictional claims in published maps and institutional affiliations. 